\title{
CONTENT AND CHEMICAL COMPOSITION OF THE ESSENTIAL OIL OF Lippia gracilis Schauer ACCESSIONS IN DIFFERENT DRYING TIMES
}

\author{
TEOR E COMPOSIÇÃO QUÍMICA DO ÓLEO ESSENCIAL DE ACESSOS DE Lippia \\ gracilis Schauer EM DIFERENTES TEMPOS DE SECAGEM
}

\author{
Juliana Oliveira de MELO $^{1 *}$; Arie Fitzgerald BLANK ${ }^{2}$; Alisson Marcel Souza de OLIVEIRA ${ }^{3}$; \\ Thiago Matos ANDRADE ${ }^{3}$; Maria de Fátima Arrigoni-Blank ${ }^{2}$; Péricles Barreto Alves ${ }^{4}$ \\ 1. Doutora em Biotecnologia, Universidade Federal de Sergipe-UFS, São Cristovão, SE, Brasil; 2. Professor, Doutor, Departamento de \\ Engenharia Agronômica, UFS, São Cristóvão, SE, Brasil; 3. Professor, Doutor, Campus do Sertão, UFS, Nossa Senhora da Glória, SE, \\ Brasil; 4. Professor, Doutor, Departamento de Química, UFS, São Cristóvão, SE, Brasil
}

\begin{abstract}
Lippia gracilis, popularly known in Brazil as 'alecrim-de-tabuleiro', is used for many purposes, especially as antimicrobial and antiseptic. The drying process of aromatic and medicinal plants aims to minimize the loss of active principles and slow their deterioration, which may greatly influence the yield and chemical composition of some species. The objective of this study was to evaluate the effect of drying times $(0$, 2,4 , and 8 days) on the content and chemical composition of the essential oil of L. gracilis accessions LGRA106, LGRA-109, and LGRA-201. The leaves were dried at $40{ }^{\circ} \mathrm{C}$, and essential oil was extracted by hydrodistillation. Chemical analysis was performed by GC/MS. The experiment was carried out in a completely randomized design with three replications. The accessions of L. gracilis LGRA-106, LGRA-109, and LGRA201 presented higher essential oil at four days of drying time. The accession LGRA-201 showed the highest essential oil yields at four and eight days of drying, with mean values of 0.038 and $0.029 \mathrm{~mL} \mathrm{~g}^{-1}$, respectively. The drying time did not influence the contents of thymol, methyl-thymol, $\gamma$-terpinene, and carvacrol in the essential oils of $L$. gracilis, but affected the contents of $\beta$-caryophyllene, $p$-cymene, and carvacrol acetate. The essential oils of the three accessions analyzed in this study revealed different chemical profiles.
\end{abstract}

KEYWORDS: Verbenaceae. Native medicinal plant. Volatile oil. Post-harvest. Drying period.

\section{INTRODUCTION}

The essential oil is a small fraction of the plant composition that can be used in the pharmaceutical, food, and fragrance industries (MARTINS et al., 1998). These substances are very complex, and their mixtures may contain about 2060 compounds at very different concentrations (BAKALI et al., 2006).

Owing to studies on biological activity, Lippia gracilis (Family: Verbenaceae), popularly known in Brazil as "alecrim-de-tabuleiro", has gained attention. Together with over 200 herbs of the Lippia genus, Lippia gracilis is distributed in South and Central America. The essential oils of these plants can be extracted from the stem, leaves, flowers, and roots, and are characterized by the presence of limonene, $\beta$-caryophyllene, $\rho$-cymene, camphor, linalool, $\alpha$-pinene, thymol, and carvacrol (PASCUAL et al., 2001).

The essential oil of $L$. gracilis has antimicrobial, larvicidal, insecticidal, antinociceptive, and anti-inflammatory activities (PASCUAL et al., 2001; AQUINO et al., 2003; PESSOA et al., 2005; ALBUQUERQUE et al., 2006). Many of these properties are attributed to the presence of the volatile compounds carvacrol and thymol.

The drying process of the aromatic and medicinal plants aims to minimize the loss of the active principle and delay its deterioration due to the reduction of the enzymatic activity, allowing the plants to be conserved for a longer period of commercialization and use. Nevertheless, the drying process affects the yield and the chemical composition of some plants, especially aromatic species, for they contain volatile substances (VON HERTWIG, 1991; COSTA, 2005). Thus, the commercialization of such unstable materials becomes a dilemma since the market demands the essential oil have a pre-established composition (BLANK et al., 2006).

Alves et al. (2018) observed that the drying time significantly influenced the major chemical compounds, but it did not affect the essential oil content of Myrcia lunidana. The drying time also influenced the chemical composition and the essential oil content of the basil cultivar Maria Bonita (Ocimum basilicum L.) (ALVES et al., 2015).

Therefore, the objective of this work was to evaluate the influence of the drying time on the 
content and chemical composition of the essential oil of Lippia gracilis accessions.

\section{MATERIAL AND METHODS}

The leaves of $L$. gracilis accessions LGRA106, LGRA-109, and LGRA-201 (voucher number 9205, 9207, and 9206, respectively), native to the municipality of Tomar do Geru-SE, were collected from the L. gracilis collection of the Active Germplasm Bank of Medicinal and Aromatic Plants of the Universidade Federal de Sergipe, located at the Experimental Farm "Campus Rural da UFS", in the municipality of São Cristóvão, state of Sergipe, Brazil (lat. $11^{\circ} 00^{\prime} \mathrm{S}$, long. $37^{\circ} 12^{\prime} \mathrm{W}$ ). The climate of the region is tropical semiarid, with mild and rainy winter, hot and dry summer. Spacing between the three plants of each accession was $1.0 \times 1.0 \mathrm{~m}$. Leaves were harvested from 12-year-old plants in September 2016.

All leaves of $L$. gracilis were dried in a forced-air-circulation oven at $40 \pm 1{ }^{\circ} \mathrm{C}$. The essential oils were obtained at the drying times of $0,2,4$, and 8 days, using samples of $100 \mathrm{~g}$ of leaves. The experiment was implemented in a completely randomized design, with three replications, testing four drying times of leaves of three $L$. gracilis accessions. The essential oils were extracted by hydrodistillation, using the Clevenger apparatus, for 140 minutes (EHLERT et al., 2006), from the moment of boiling. The essential oils were stored at $-20 \pm 2{ }^{\circ} \mathrm{C}$ in an amber flask for further chemical analysis. The essential oil content was obtained by dividing the essential oil volume by the dry mass.

Leaves initial moisture was determined immediately after collection in a forced-aircirculation oven at $105 \pm 2{ }^{\circ} \mathrm{C}$, for $48 \mathrm{~h}$. Data were obtained using three $100 \mathrm{~g}$ samples.

The qualitative analysis of the chemical composition of the essential oil was carried out by gas chromatography (GC) coupled with mass spectrometry (MS) (GC-MS; QP 5050A, Shimadzu). The instrument was equipped with an AOC-20i (Shimadzu) autosampler and a $\mathrm{J} \& \mathrm{~W}$ Scientific fused silica capillary column $(5 \%$ phenyl-95\% -dimethylpolysiloxane; $30 \mathrm{~m}$ x 0.25 mm i.d., $0.25 \mu \mathrm{m}$ film thickness), using $\mathrm{He}$ as carrier gas, at a flow rate of $1.2 \mathrm{~mL} / \mathrm{min}$.

The oven temperature was programmed to $50^{\circ} \mathrm{C}$ for $1.5 \mathrm{~min}$, with an increase of $4^{\circ} \mathrm{C} / \mathrm{min}$ to $200^{\circ} \mathrm{C}$, then $10^{\circ} \mathrm{C} / \mathrm{min}$ to $280^{\circ} \mathrm{C}$, keeping this temperature constant for $5 \mathrm{~min}$. The injector temperature was $250{ }^{\circ} \mathrm{C}$, and detector temperature (or interface) was $280{ }^{\circ} \mathrm{C}$. Essential oils were diluted with ethyl acetate, and an injection volume of $0.5 \mu \mathrm{L}$ was employed, with a split ratio of $1: 83$, and column pressure of $64.20 \mathrm{kPa}$. The MS data were obtained by electronic ionization with electron energy of $70 \mathrm{eV}$; at a scan rate of 1,000 ; scan interval of 0.50 fragments $/ \mathrm{s}$; detecting fragments with $\mathrm{m} / \mathrm{z}$ from 40 to $500 \mathrm{Da}$.

The essential oils compounds were identified by comparing the mass spectra in the library (ADAMS, 2007) with those contained in the database of the equipment (NIST21 and NIST107), and by comparing the retention indices with those in literature. The Kovats retention indices (IK) were determined using a homologous series of n-alkanes $\left(\mathrm{C}_{8}-\mathrm{C}_{18}\right)$ injected under the same chromatographic conditions of the samples, using the Van den Dool and Kratz equation (VAN DEN DOOL H, 1963).

Data were subject to mean analysis of variance (ANOVA). Values with significant differences were compared by the Tukey's test, at $5 \%$ of probability. Statistical analyses were performed using the SISVAR software.

\section{RESULTS AND DISCUSSION}

The accession LGRA-201 presented the highest essential oil yields at four and eight days of drying, with mean values of 0.038 and $0.029 \mathrm{~mL} \mathrm{~g}^{-1}$, respectively. In the two-day drying time, LGRA-201 also showed high essential oil yield $\left(0.030 \mathrm{~mL} \mathrm{~g}^{-1}\right)$; however, it did not differ from the accession LGRA$106\left(0.026 \mathrm{~mL} \mathrm{~g}^{-1}\right)$ (Table 1). When using fresh leaves (0-day drying time), LGRA-201 did not vary from LGRA-109, with values of $0.016 \mathrm{~mL} \mathrm{~g}^{-1}$ for both accessions.

All the accessions showed a quadratic behavior for the essential oil yields in function of the drying time. The derivation of equations revealed that the points of maximum essential oil yield of the accessions LGRA106, LGRA109, and LGRA201 were $0.025,0.023$, and $0.038 \mathrm{~mL} \mathrm{~g}^{-1}$, respectively. These values were reached by drying leaves for 4.8, 5.5, and 4.9 days (Figure 1).

Luz et al. (2009), in a study with Ocimum gratissimum, verified a reduction from $3.0 \mathrm{~mL} \mathrm{~g}^{-1}$ to $1.6 \mathrm{~mL} \mathrm{~g}^{-1}$ in the essential oil from the first to the eighth day of drying. This fact reveals that the best option to potentiate essential oils yield is to extract the substance directly from fresh leaves. However, the results obtained in the present research show that, for L. gracilis, the extraction of essential oil from fresh leaves is less efficient in obtaining higher essential oil content. 
Table 1. Essential oil yield $\left(\mathrm{mL} \mathrm{g}^{-1}\right)$ and contents of $\beta$-caryophyllene, $\rho$-cymene, and carvacrol acetate (\%) of three accessions of Lippia gracilis, in function of different drying times.

\begin{tabular}{|c|c|c|c|c|}
\hline \multirow{2}{*}{ Accession } & \multicolumn{4}{|c|}{ Drying times (days) } \\
\hline & 0 & 2 & 4 & 8 \\
\hline & \multicolumn{4}{|c|}{ Essential oil yield $\left(\mathrm{mL} \mathrm{g}^{-1}\right)$} \\
\hline LGRA-106 & $0.011 \mathrm{~b}$ & $0.026 \mathrm{ab}$ & $0.020 \mathrm{~b}$ & $0.020 \mathrm{~b}$ \\
\hline LGRA-109 & $0.016 \mathrm{a}$ & $0.022 \mathrm{~b}$ & $0.022 \mathrm{~b}$ & $0.022 \mathrm{~b}$ \\
\hline LGRA-201 & $0.016 \mathrm{a}$ & $0.030 \mathrm{a}$ & $0.038 \mathrm{a}$ & $0.029 \mathrm{a}$ \\
\hline \multirow[t]{2}{*}{ C.V. $(\%)$} & \multicolumn{4}{|c|}{8.69} \\
\hline & \multicolumn{4}{|c|}{$\beta$-caryophyllene } \\
\hline LGRA-106 & $6.54 \mathrm{a}$ & $6.50 \mathrm{a}$ & $5.31 \mathrm{a}$ & $7.65 \mathrm{a}$ \\
\hline LGRA-109 & $3.73 \mathrm{c}$ & $4.89 \mathrm{~b}$ & $4.76 \mathrm{a}$ & $5.54 \mathrm{~b}$ \\
\hline LGRA-201 & $4.97 \mathrm{~b}$ & $5.27 \mathrm{~b}$ & $4.82 \mathrm{a}$ & $4.27 \mathrm{c}$ \\
\hline \multirow[t]{2}{*}{ C.V. (\%) } & \multicolumn{4}{|c|}{9.79} \\
\hline & \multicolumn{4}{|c|}{$\rho$-cymene } \\
\hline LGRA-106 & $5.75 \mathrm{~b}$ & $6.99 \mathrm{~b}$ & $6.69 \mathrm{~b}$ & $5.96 \mathrm{~b}$ \\
\hline LGRA-109 & $11.22 \mathrm{a}$ & $11.08 \mathrm{a}$ & $11.36 \mathrm{a}$ & $10.82 \mathrm{a}$ \\
\hline LGRA-201 & $10.28 \mathrm{a}$ & $10.41 \mathrm{a}$ & $11.30 \mathrm{a}$ & $11.95 \mathrm{a}$ \\
\hline \multirow[t]{2}{*}{ C.V. $(\%)$} & \multicolumn{4}{|c|}{6.12} \\
\hline & \multicolumn{4}{|c|}{ Carvacrol acetate } \\
\hline LGRA-106 & $0.00 \mathrm{~b}$ & $0.00 \mathrm{~b}$ & $0.00 \mathrm{~b}$ & $0.00 \mathrm{~b}$ \\
\hline LGRA-109 & $1.18 \mathrm{a}$ & $0.59 \mathrm{a}$ & $0.56 \mathrm{a}$ & $0.44 \mathrm{a}$ \\
\hline LGRA-201 & $0.00 \mathrm{~b}$ & $0.00 \mathrm{~b}$ & $0.00 \mathrm{~b}$ & $0.00 \mathrm{~b}$ \\
\hline
\end{tabular}

Means followed by the same letter in the columns do not differ by the Tukey's test $(\mathrm{p}<0.05)$.

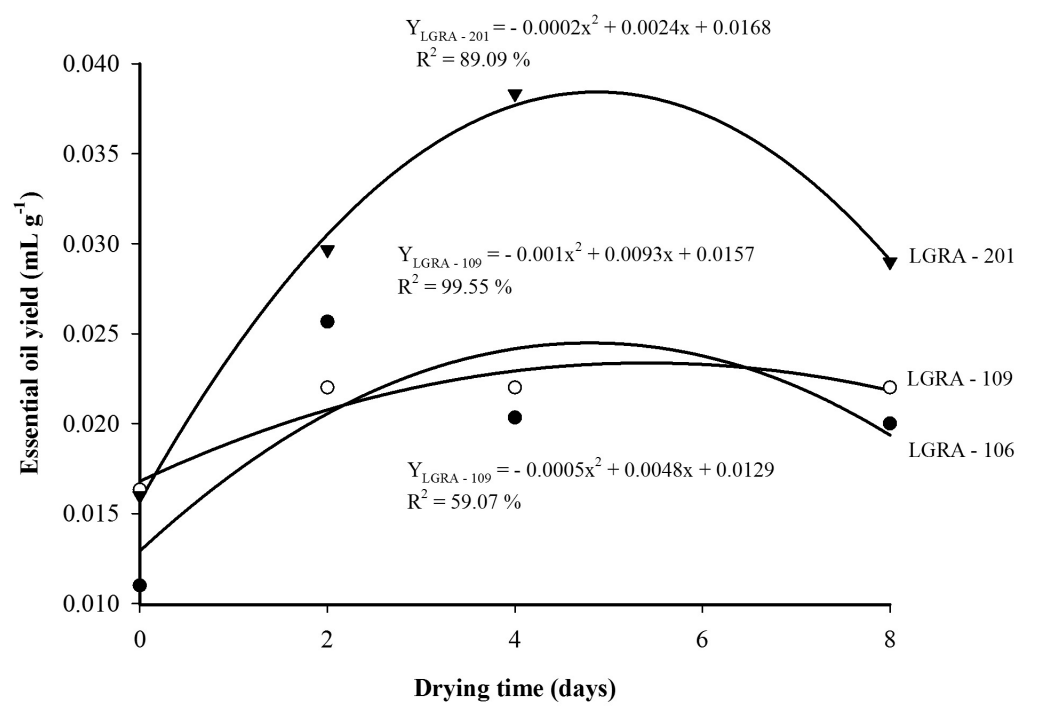

Figure 1. Essential oil yield of three $L$. gracilis accessions in function of different drying times.

The use of fresh or dried leaves has some advantages and disadvantages. The advantage is the short period and low costs with electric power in the obtainment of the substance since the forced-aircirculation ovens would not be used. The disadvantages are the room required for storage, and the transport of the leaves. In addition, the high humidity of the leaves would keep the hydrolytic enzymes active, which could reduce the biological activity of the active principle of these oils. 
LGRA-106 showed higher $\beta$-caryophyllene contents at the zero, six, and eight-day drying time, not differing from the other accessions with fourday drying time (5.31\%). However, LGRA-106 showed the lowest $\rho$-cymene content in all drying times $(5.75,6.99,6.69,5.96 \%)$. LGRA-109 was the only one that exhibited carvacrol acetate in all drying times (Table 1).
All the accessions showed a quadratic behavior for the $\beta$-caryophyllene content in function of the drying time. The derivation of equations revelaed that the point of minimum $\beta$-caryophyllene content of the accession LGRA106 was 5.275\%, reached by 3.4 days of drying time; and the maximum $\beta$-caryophyllene content of the accessions LGRA109 and LGRA201 were 5.50\% and 5.09\%, reached by 8 and 1.5 days of drying time (Figure 2).

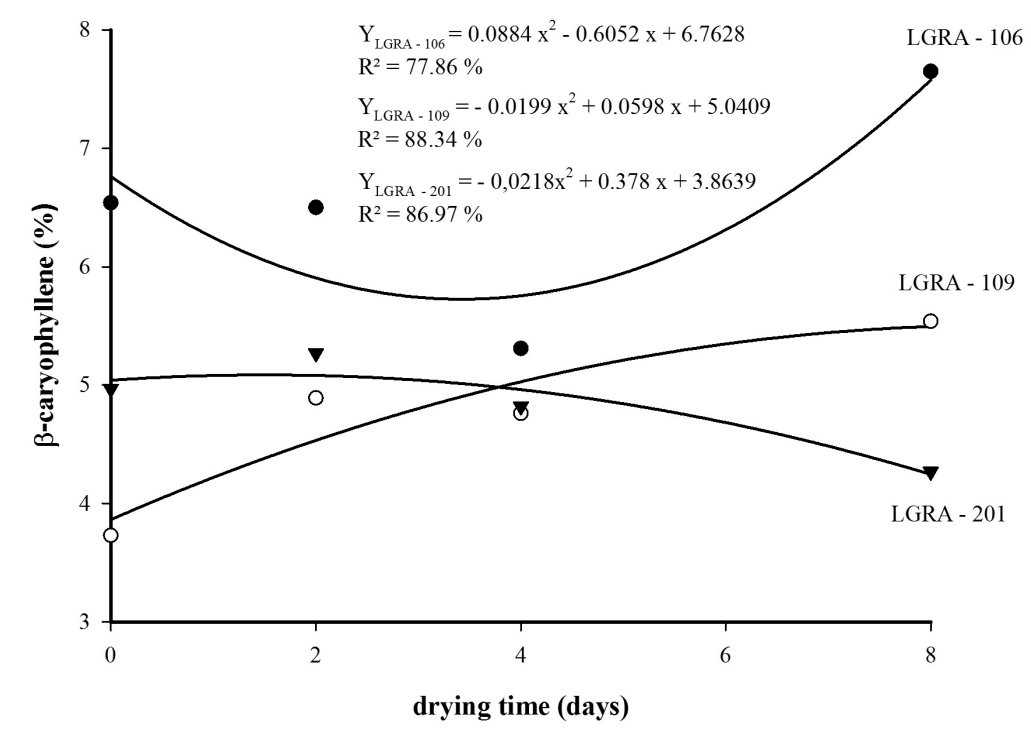

Figure 2. $\beta$-caryophyllene content of three accessions of $L$. gracilis in function of different drying times.

Regarding $p$-cymene, LGRA-201 had an increasing linear trend for the production of this compound, with higher values at the eight-day drying time (12\%). The accessions LGRA-106 and LGRA-109 showed a quadratic behavior for the $p$ cymene content in function of drying time. The derivation of equations revealed that the points of maximum $p$-cymene content of the accessions LGRA106 and LGRA109 were $6.93 \%$ and $11.26 \%{ }^{1}$, respectively, reached by drying leaves for 4.0 and 2.7 days (Figure 3 ).

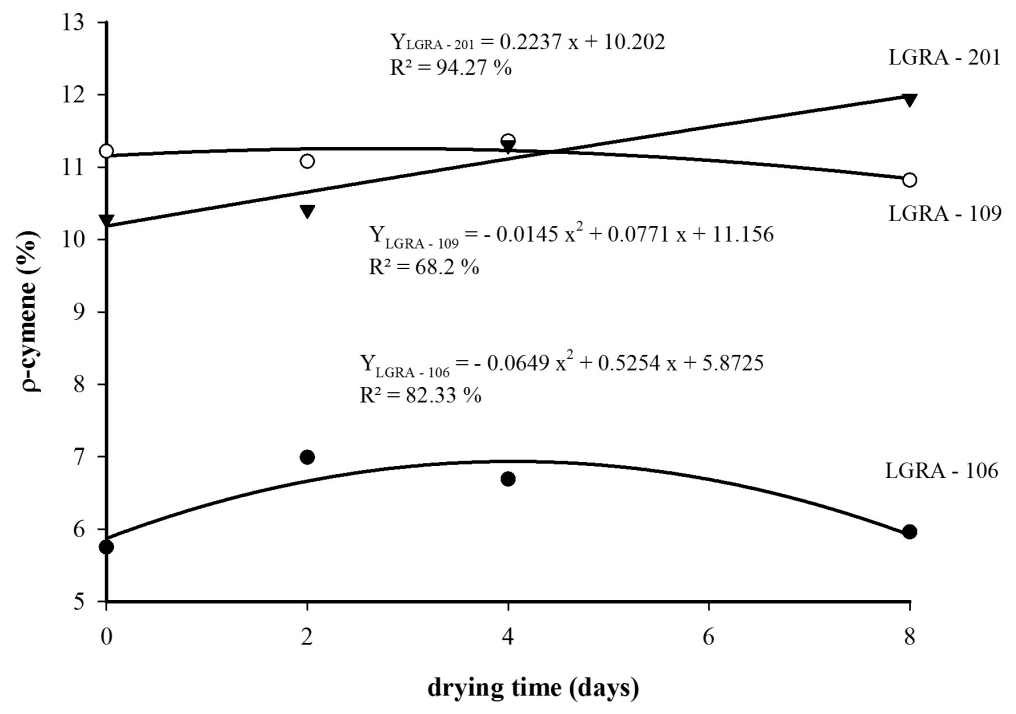

Figure 3. $p$-cymene content of three accessions of $L$. gracilis in function of different drying times. 
LGRA-109 showed a sharp reduction in the carvacrol acetate content after the first drying time. This decrease was maintained until the sixth day, and on the eighth day, a slight increase in the production of this compound was observed (Figure $4)$.

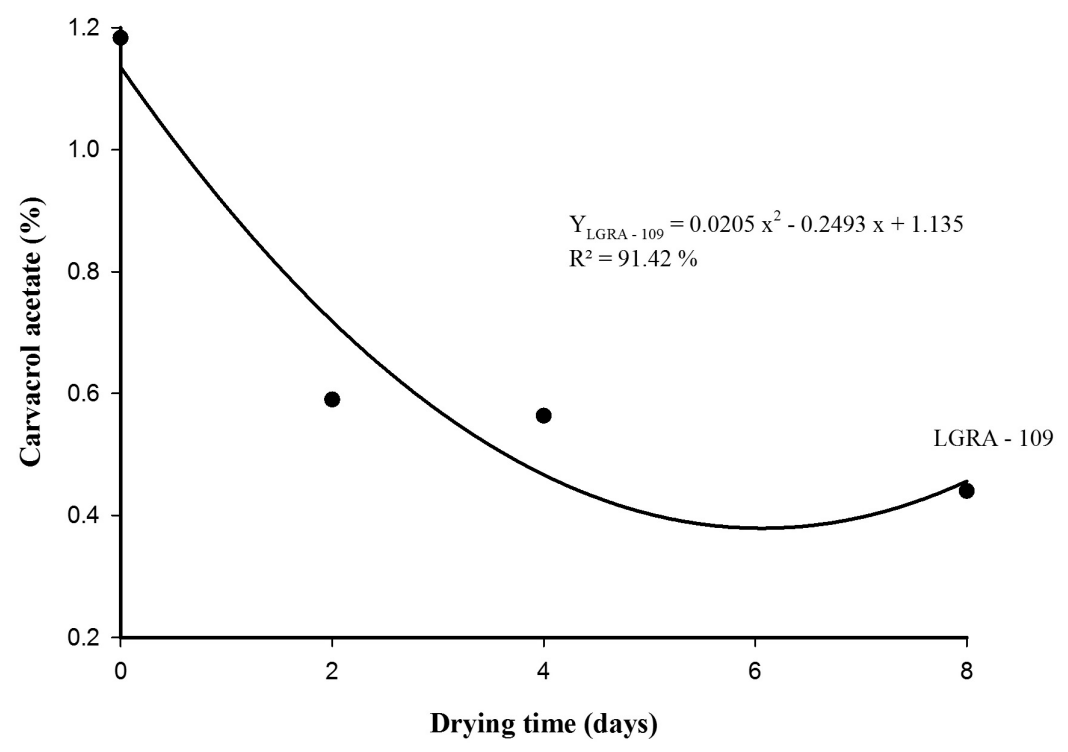

Figure 4. Carvacrol acetate content of L. gracilis accession LGRA-109, in function of different drying times.

In relation to the chemical composition of the essential oils of the three accessions of $L$. gracilis, LGRA-106 showed higher contents of thymol (63.81\%) and methylthymol (8.14\%); LGRA-109 showed higher carvacrol content
(53.77\%), differing statistically from the other accessions; and LGRA-201 exhibited higher $\gamma$ terpinene content $(21.53 \%)$ than the other accessions (Table 2).

Table 2. Chemical composition of the essential oil of three accessions of L. gracilis.

\begin{tabular}{ccccc}
\hline \multirow{2}{*}{ Accession } & \multicolumn{4}{c}{ Compound (\%) } \\
\cline { 2 - 5 } & Thymol & Methyl-thymol & $\gamma$-Terpinene & Carvacrol \\
\hline LGRA-106 & $63.81 \mathrm{a}$ & $8.14 \mathrm{a}$ & $4.04 \mathrm{c}$ & $0.00 \mathrm{c}$ \\
LGRA-109 & $3.52 \mathrm{c}$ & $4.97 \mathrm{~b}$ & $9.37 \mathrm{~b}$ & $53.77 \mathrm{a}$ \\
LGRA-201 & $6.47 \mathrm{~b}$ & $0.00 \mathrm{c}$ & $21.53 \mathrm{a}$ & $40.68 \mathrm{~b}$ \\
\hline CV (\%) & 11.34 & 4.80 & 8.82 & 6.48 \\
\hline
\end{tabular}

Means followed by the same letter in the columns do not differ by the Tukey's test $(p<0.05)$

The chemical composition of the essential oil of $L$. gracilis revealed quantitative fluctuations of the major compounds due to genetic and abiotic conditions.

Neves et al. (2008) determined the chemical compounds found in the essential oil of $L$. gracilis in two sites of the caatinga of Pernambuco, Buíque and Ouricuri, by Gas Chromatography (GC) and Gas Chromatography coupled with Mass Spectrometry (GC/MS). The study revealed that carvacrol and p-cymene were the major compounds in Buíque, and that thymol, $\gamma$-terpinene, and 4methoxy acetophenone were the major compounds in Ouricuri.

The drying time did not statistically influence the chemical composition of the essential oil of L. gracilis, i.e., the compounds thymol, methyl thymol, $\gamma$-terpinene, and carvacrol did not differ statistically in relation to the drying times (Table 3). However, the increase or reduction of the compounds may be caused by oxidation, reduction, and rearrangement reactions during the drying process due to the temperature or the drying time (RADÜNZ et al., 2003).

Radünz et al. (2002), studying different drying techniques for L. sidoides, also reported no significant variations in the thymol content $(83.5 \%)$, which was one of the major compounds of the essential oil of the species. The drying time significantly affected the content of the major chemical compounds of the essential oil of Myrcia lunidana (ALVES et al., 2018). 
Table 3. Chemical composition of the essential oil of L. gracilis in function of different drying times.

\begin{tabular}{ccccc}
\hline \multirow{2}{*}{ Drying times (days) } & \multicolumn{4}{c}{ Compound (\%) } \\
\cline { 2 - 5 } & Thymol & Methyl-thymol & $\gamma$-Terpinene & Carvacrol \\
\hline 0 & $25.75 \mathrm{a}$ & $4.55 \mathrm{a}$ & $11.58 \mathrm{a}$ & $31.03 \mathrm{a}$ \\
2 & $23.42 \mathrm{a}$ & $4.26 \mathrm{a}$ & $12.02 \mathrm{a}$ & $31.00 \mathrm{a}$ \\
4 & $24.24 \mathrm{a}$ & $4.32 \mathrm{a}$ & $12.12 \mathrm{a}$ & $30.94 \mathrm{a}$ \\
8 & $24.99 \mathrm{a}$ & $4.36 \mathrm{a}$ & $10.86 \mathrm{a}$ & $32.96 \mathrm{a}$ \\
\hline $\mathrm{CV}(\%)$ & 11.34 & 4.80 & 8.82 & 6.48 \\
\hline
\end{tabular}

Means followed by the same letter in the columns do not differ by the Tukey's test $(\mathrm{p}<0.05)$

A study carried out by Albuquerque et al. (2006) showed that the essential oil of L. gracilis has antimicrobial activity against fungi and bacteria. The study confirmed the inhibition of the bacteria Salmonela choleraceuis-diarizonae, Enterobacter asburiae, Bacillus thuringiensis, Bacillus pumilis, Kleibsiella pneumoniae, Enterobacter hormaechei, and Bacillus cereus in the presence of the essential oil of $L$. gracilis. This activity was associated with the presence of two phenolic monoterpenes, carvacrol $(41.77 \%)$ and thymol (10.13\%).
This study demonstrated the variation in the essential oil content of the leaves of $L$. gracilis accessions LGRA-106, LGRA-109, and LGRA-201 when subject to different drying times. The drying times of four and six days resulted in the highest oil contents.

In addition, results showed that the essential oils of the three accessions exhibited different chemical profiles, which could justify the different essential oil contents and composition of the studied genetic materials.

RESUMO: Lippia gracilis, conhecida popularmente como alecrim-de-tabuleiro é usada para muitos efeitos, especialmente como antimicrobiano e antisséptico. O processo de secagem das plantas aromáticas e medicinais visa minimizar a perda de princípios ativos e retardar a sua deterioração os mesmos podem afetar sobremaneira o rendimento e a composição química de algumas plantas. O objetivo deste trabalho foi avaliar o efeito de diferentes tempos de secagem (0,2, 4 e 8 dias) no teor e na composição química do óleo essencial dos acessos LGRA-106, LGRA-109 e LGRA-201 de L. gracilis. As folhas foram secas a $40{ }^{\circ} \mathrm{C}$ e a extração do óleo essencial foi por hidrodestilação. A análise química foi feita através CG/EM. O ensaio foi implantado em delineamento inteiramente casualizado com três repetições. Os acessos de L. gracilis LGRA-106, LGRA- 109 e LGRA-201 apresentaram maiores rendimentos de óleo essencial no tempo de secagem de quatro dias. O acesso LGRA-201 apresentou os maiores teores de óleo essencial aos quatro e oito dias de secagem, com valores médios de 0,038 e $0,029 \mathrm{~mL} \mathrm{~g}^{-1}$, respectivamente. O tempo de secagem não influenciou os teores de timol, metil-timol, terpineno e carvacrol nos óleos essenciais de $L$. gracilis, porém afetou os teores de $\beta$-cariofileno, $\rho$ cimeno, and acetato de carvacrol. Os óleos essenciais dos três acessos analisados apresentaram perfis químicos diferentes entre si.

PALAVRAS-CHAVE: Verbenaceae. Planta medicinal nativa. Óleo volátil. Pós colheita. Período de secagem.

\section{REFERENCES}

ADAMS, R. P. Identification of Essential Oils by Gas Chromatography/Mass Spectrometry. 4. ed. Illinois: Allured Publishing Corporation, 2007. 803 p.

ALBUQUERQUE, C. C.; CAMARA, T. R.; MARIAN, R. L. R.; LILIA, W. L.; MARCELINO JÚNIOR, C.; ULISSES, C. Antimicrobial Action of the Essential Oil of Lippia gracilis Schauer. Brazilian Archives of Biology and Technology, Curitiba, v. 49, n. 4, p. 527-535, jul. 2006. http://dx.doi.org/10.1590/S151689132006000500001. 
ALVES, M. F.; BLANK, A. F.; ANDRADE, T. M.; NIZIO, D. A. C.; SAMPAIO, T. S.; NASCIMENTO JUNIOR, A. F. Content and chemical composition of the essential oil of Myrcia lundiana Kiaersk in different drying times. Journal Bioscience, Uberlândia, v. 34, n. 3, p. 623-628, May/June 2018.

https://doi.org/10.14393/BJ-v34n3a2018-39371

ALVES, M. F.; BLANK, A. F.; ARRIGONI-BLANK, M. F.; FONTES, S. S.; JESUS, H. C. R.; ALVES, P. B. Establishment of methodology for drying leaves and storage of essential oil of linalool chemotype Ocimum basilicum L. Journal Bioscience, Uberlândia, v. 31, n. 5, p. 1441-1449, Sept./Oct. 2015. http://dx.doi.org/10.14393/BJ-v31n5a2015-22056

AQUINO, P. L. P.; LIMA, E. O.; FARIAS, M. P.; FREIRE, K. R. L.; SOUZA, E. L,; CECHINEL FILHO, V. Atividade antifúngica de maleimidas contra dermatófitos isolados de Tinea captis. Revista Brasileira de Análises Clínicas, Rio de Janeiro, n. 4, p. 191-194, 2003.

BLANK, A. F.; CARVALHO FILHO, J. L. S.; ALVES, P. B.; EHLERT, P. A. D.; MELO, A. S.; CAVALCANTI, S. C. H.; ARRIGONI-BLANK, M. F.; SILVA-MANN, R. Influence of the harvesting time, temperature and drying period on basil (Ocimum basilicum L.) essential oil. Revista Brasileira de Farmacognosia, Curitiba, v. 16, n. 1, p. 24-30, jan/mar. 2006. http://dx.doi.org/10.1590/S0102$695 X 2006000100007$.

COSTA, L. C. B.; CORRÊA, R. M.; CARDOSO, J. C. W.; PINTO, J. E. B. P.; BERTOLUCCI, S. K. V.; FERRI, P. H. Secagem e fragmentação da matéria seca no rendimento e composição do óleo essencial de capim-limão. Horticultura Brasileira, Brasília, v. 23, n. 4, p. 956-959, out/dez. 2005.

http://dx.doi.org/10.1590/S0102-05362005000400019.

EHLERT, P. A. D.; BLANK, A. F.; ARRIGONI-BLANK, M. F.; PAULA, J. W. A.; CAMPOS, D. A.; ALVIANO, C. S. Tempo de hidrodestilação na extração de óleo essencial de sete espécies de plantas medicinais. Revista Brasileira de Plantas Medicinais, Botucatu, v. 8, n. 2, p. 79-80, 2006.

EVANS, W. C. Trease and Evans' Pharmacognosy. 14. ed. London: WB Saunders Company, 1996. cap. 7.

GOBBO-NETO, L.; LOPES, N. P. Plantas medicinais: fatores de influência no conteúdo de metabólitos secundários. Química Nova, São Paulo, v. 30, n. 2, p. 374-381, out. 2007. DOI: 10.1590/S010040422007000200026.

KUMAR, N.; SHUKLA, R.; CHANOTIYA, C. S.; YADAV, A.; SINGH, A. K.; BAGCHI, G. D. Effect of seasons and drying on the essential oil composition of leaf in Ocimum kilimandscharicum Guerke. The Journal of Essencial Oil Research, Berlin, v. 21, n. 5, p. 400-402, jan. 2009.

http://dx.doi.org/10.1080/10412905.2009.9700202.

LUZ, J. M. Q.; EHLERT, P. A. D.; INNECCO, R. Horário de colheita e tempo de secagem da alfavaca-cravo. Horticultura Brasileira, Brasília, v. 27, p. 539-542, ago. 2009. http://dx.doi.org/10.1590/S010205362009000400022.

MARTINS, E. R.; CASTRO, D. M.; CASTELLANI, D. C.; DIAS, J. E. Plantas medicinais. 2. ed, Viçosa: Editora UFV, 1998. 220 p.

MASOTTI, V; JUTEAU, F; BESSIÉRE, JM; VIANO, J. Seasonal and phenological variations of the essential oil from the narrow endemic species Artemisia molinieri and its biological activities. Journal of Agricultural and Food Chemistry, Washington, v. 51, p. 7115-7121, nov. 2003.

http://pubs.acs.org/doi/abs/10.1021/jf034621y.

NEVES, I. A.; OLIVEIRA, J. C. S.; CAMARA, C. A. G.; SCHWARTZ, M. O. E. Chemical Composition of the Leaf Oils of Lippia gracilis Schauer from two Localities of Pernambuco. Journal of Essential Oil Research, Berlin, v. 20, p. 157-160, dez. 2008. http://dx.doi.org/10.1080/10412905.2008.9699979. 
PASCUAL, M. E.; SLOWING, K.; CARRETERO, E.; MATA, D. S.; VILLAR, A. Lippia: traditional uses, chemistry and pharmacology: a review. Journal of Ethnopharmacology, v. 76, p. 201-214, ago. 2001. https://doi.org/10.1016/S0378-8741(01)00234-3.

PESSOA, O. D. L.; CARVALHO, C. B. M.; SILVESTRE, J. O. V. L.; LIMA, M. C. L.; NETO, R. M.; MATOS, F. J. A.; LEMOS, T. L. G. Antibacterial activity of the essential oil from Lippia aff. gracilis. Fitoterapia, v. 76, p. 712-714, out. 2005. https://doi.org/10.1016/j.fitote.2005.07.004.

RADÜNZ, L. L.; MELO, E. C.; BERBERT, P. A.; BARBOSA, L. C. A.; ROCHA, R. P.; GRANDI, A. M. Efeitos da temperatura do ar de secagem sobre a qualidade do óleo essencial de alecrim pimenta (Lippia sidoides Cham). Revista Brasileira de Armazenamento, Viçosa, v. 27, n. 2, p. 9-13, jan. 2002.

RADÜNZ, L. L.; MELO, E. C.; BERBERT, P. A.; BARBOSA, L. C. A.; SANTOS, R. H. S. ; ROCHA, RP. Influência da temperatura do ar de secagem na quantidade do óleo essencial extraído de guaco (Mikania glomerata Sprengel). Revista Brasileira de Armazenamento, Viçosa, v. 28, n. 2, p. 41-45, 2003.

VAN DEN DOOL, H.; KRATZ, J. D. J. A generalization of the retention index system including linear temperature programmed gas-liquid partition chromatography. Journal of Chromatography, v. 11, p. 463471, 1963. https://doi.org/10.1016/S0021-9673(01)80947-X

VON HERTWIG, I. F. Plantas aromáticas e medicinais: plantio, colheita, secagem, comercialização. 2. ed. São Paulo: Editora Ícone, 1991. 414 p. 